\title{
THE STUDY OF CUTANEOUS MANIFESTATIONS OF MALIGNANT DISEASES
}

\author{
Sangameshwara G. $M^{1}$, Venkatesh $U^{2}$, Indudhara P. $B^{3}$, Ganga $H^{4}$, Lohith $S^{5}$ \\ ${ }^{1}$ Associate Professor, Department of Dermatology, Subbaiah Institute of Medical Sciences, Shimoga. \\ 2 Professor \& HOD, Department of ENT, Raichur Institute of Medical Sciences, Raichur. \\ ${ }^{3}$ Assistant Professor, Department of Pathology, Subbaiah Institute of Medical Sciences, Shimoga. \\ ${ }^{4}$ Assistant Professor, Department of Pathology, Subbaiah Institute of Medical Sciences, Shimoga. \\ ${ }_{5}^{5}$ Assistant Professor, Department of ENT, Subbaiah Institute of Medical Sciences, Shimoga.
}

\section{ABSTRACT}

\section{BACKGROUND}

Malignancy affecting the organs is reflected on to the skin in the form of specific or nonspecific lesions. This study is aimed at determining the incidence of cutaneous manifestations among patients with various malignancies.

\section{MATERIAL AND METHODS}

100 cases of biopsy proven malignancies were taken for the study from November to December 2013 attending oncology outpatient and inpatient department at Father Muller Medical College Hospital, Mangalore, Karnataka. Post radiation and chemotherapy therapy patients were excluded from the study, but recurrence after the surgery were included.

\section{RESULT}

Out of 100 cases studied, skin changes seen in 15 cases. The cutaneous metastases were seen in 6 (6\%), out of which 5 (5\%) were contiguous and $1(1 \%)$ was non-contiguous. Nonspecific skin changes seen in 9 (9\%) cases, in which commonest was acquired ichthyosis, 3 (3\%) seen in carcinoma oesophagus, 2 (2\%) in carcinoma stomach and $1(1 \%)$ in Non-Hodgkin's lymphoma. Generalised pruritus, petechial haemorrhage, acanthosis nigricans seen in hepatocellular carcinoma, acute lymphatic leukaemia and carcinoma breast 1 case each respectively.

\section{CONCLUSION}

Cutaneous metastasis occurs late in malignancy and relapse after surgery seen in some cases. Early recognition and treatment of cutaneous metastasis will help in prolonging the life of patient.

\section{KEYWORDS}

Cutaneous Metastasis, Malignant Neoplasm, Contiguous, Non-Contiguous.

HOW TO CITE THIS ARTICLE: Sangameshwara GM, Venkatesh U, Indudhara PB, et al. The study of cutaneous manifestations of malignant diseases. J. Evolution Med. Dent. Sci. 2016;5(33):1836-1838, DOI: 10.14260/jemds/2016/432

\section{INTRODUCTION}

Skin is the mirror of internal disorder where malignancy is reflected on to the skin, may be in the form of specific malignant infiltrate and nonspecific lesions. Specific infiltrate may be contiguous or non-contiguous that will reveal malignant cells on histopathology.

\section{MATERIAL AND METHODS}

After obtaining approval from Institutional Ethical Committee and informed consent from the patients, 100 cases of histopathologically proven primary malignancies of all age group of varying duration involving different body organs attending oncology outpatient and inpatient department were randomly taken for the present study. Detailed history about duration of malignancy and duration between onset of malignancy and skin changes recorded. Cutaneous and systemic examination was done, biopsy of cutaneous lesions were taken and subjected for histopathological examination.

Financial or Other, Competing Interest: None.

Submission 25-02-2016, Peer Review 31-03-2016,

Acceptance 06-04-2016, Published 25-04-2016.

Corresponding Author:

Dr. Sangameshwara G. M,

Associate Professor,

Department of Dermatology,

Subbaiah Institute of Medical Sciences,

Shimoga.

E-mail: drsangameswara@yahoo.in

DOI: $10.14260 /$ jemds/2016/432
Clinical photographs were also taken. Data collected was analysed and compared with similar studies conducted elsewhere.

\section{Inclusion Criteria}

1. First time diagnosed malignancies without any previous cancer therapy.

2. Patients with recurrence after the surgery who had not received pre or postoperative radiotherapy or chemotherapy.

\section{Exclusion Criteria}

Patients treated with radiation or chemotherapy previously.

\section{RESULTS}

Total number of cases studied were 100 , out of which 52 $(52 \%)$ patients were male and $48(48 \%)$ patients were female; $49(49 \%)$ patients were above the age of 50 yrs., 27 (27\%) cases in $4^{\text {th }}$ decade, $13(13 \%)$ cases in $3^{\text {rd }}$ decade, $6(6 \%)$ cases in $2^{\text {nd }}$ decade and least was seen in $1^{\text {st }}$ decade with $5(5 \%)$ cases.

In the present study tumours found in males were carcinoma of the oropharynx (12), carcinomas of the oesophagus (7), oral cavity (6), larynx (6), acute lymphatic leukaemia (4), rectum (3), carcinoma lung (2), stomach (2) and other malignancies seen one each in, carcinoma nasopharynx, Multiple myeloma, Metastatic adenocarcinoma, Ewing's sarcoma left arm, Carcinoma of prostate, Carcinoma bladder, Carcinoma cerebellopontine angle, Carcinoma penis, 
Pituitary adenocarcinoma and Metastatic carcinoma of unknown origin.

Malignancies found in females were carcinoma cervix (10), carcinoma breast (10), carcinomas of the ovary (6), stomach (4), oropharynx (3), oesophagus (3), rectum (3), acute lymphatic leukaemia (2), oral cavity (2) and other malignancies seen one each in Hepatocellular carcinoma, NonHodgkin's lymphoma, Carcinoma pancreas, Pleomorphic adenocarcinoma left parotid and Metastatic carcinoma of lumbar spine.

Out of 100 cases studied, specific skin metastasis seen in $6(6 \%)$ cases, among which $5(5 \%)$ cases were contiguous and 1 (1\%) was non-contiguous. Ulcer was noted in 2 cases and skin nodules were noted in 6 cases (Table 1) and nonspecific skin lesions in $9(9 \%)$ cases.

\section{Non-Specific Skin Lesion}

Nonspecific skin changes seen in $9(9 \%)$ cases, in which commonest was acquired ichthyosis, 3 (3\%) seen in carcinoma oesophagus, $2(2 \%)$ in carcinoma stomach and $1(1 \%)$ in nonHodgkin's lymphoma. Generalized pruritus, petechial haemorrhage and acanthosis nigricans found 1 each in hepatocellular carcinoma, acute lymphatic leukaemia and carcinoma breast respectively. Drug eruption in the form of generalized maculopapular rashes due to Zoledronic acid infusion was seen in 1 case of carcinoma rectum.

\begin{tabular}{|c|c|c|c|c|}
\hline $\mathbf{A}$ & Contiguous & & & \\
\hline $\begin{array}{l}\text { Sl. } \\
\text { No. }\end{array}$ & $\begin{array}{c}\text { Skin } \\
\text { Lesions }\end{array}$ & Type & Site & $\begin{array}{c}\text { No. of } \\
\text { Patients }\end{array}$ \\
\hline 1. & $\begin{array}{c}\text { Nodules- } \\
\text { multiple } \\
\text { Ulcer-single }\end{array}$ & Ca breast (Lt) & Chest & 1 \\
\hline 2. & $\begin{array}{c}\text { Nodules- } \\
\text { multiple } \\
\text { Ulcer - } \\
\text { single } \\
\end{array}$ & Ca penis & Perineum & 1 \\
\hline 3. & $\begin{array}{l}\text { Nodule - } \\
\text { multiple }\end{array}$ & Ca breast (Rt) & Chest & 1 \\
\hline 4. & $\begin{array}{l}\text { Nodule - } \\
\text { multiple }\end{array}$ & $\begin{array}{l}\text { Hepatocellular } \\
\text { carcinoma }\end{array}$ & $\begin{array}{l}\text { Face, } \\
\text { neck, } \\
\text { chest, } \\
\text { abdomen, } \\
\text { back, } \\
\text { arms and } \\
\text { thigh }\end{array}$ & 1 \\
\hline 5. & $\begin{array}{l}\text { Nodules - } \\
\text { multiple }\end{array}$ & $\begin{array}{c}\text { Ca } \\
\text { Nasopharynx }\end{array}$ & $\begin{array}{l}\text { Face, } \\
\text { neck, } \\
\text { chest, } \\
\text { abdomen, } \\
\text { back, } \\
\text { arms and } \\
\text { thigh }\end{array}$ & \\
\hline B & $\begin{array}{c}\text { Non- } \\
\text { contiguous }\end{array}$ & & & \\
\hline 1. & $\begin{array}{l}\text { Nodule - } \\
\text { multiple }\end{array}$ & $\begin{array}{c}\mathrm{Ca} \\
\text { oropharynx } \\
\text { (Rt) }\end{array}$ & $\begin{array}{l}\text { Face, } \\
\text { neck, } \\
\text { chest }\end{array}$ & 1 \\
\hline
\end{tabular}

\begin{tabular}{|c|c|c|c|c|c|}
\hline Site & $\begin{array}{c}\text { Brown- } \\
\text { stein } \\
\text { et al \% }\end{array}$ & $\begin{array}{c}\text { Thakaram } \\
\text { et al \% }\end{array}$ & $\begin{array}{c}\text { Rajagopal } \\
\text { et al \% }\end{array}$ & $\begin{array}{c}\text { Ayyam- } \\
\text { perumal } \\
\text { et al \% }\end{array}$ & $\begin{array}{c}\text { Present } \\
\text { Study } \\
\%\end{array}$ \\
\hline Scalp & 5 & 8 & 10 & 4 & Nil \\
\hline Face & 6 & 5 & 14 & 9 & 5 \\
\hline Neck & 12 & 6 & 5 & 11 & 9 \\
\hline $\begin{array}{c}\text { Upper } \\
\text { Extremity }\end{array}$ & 6 & 10 & 10 & 9 & 8 \\
\hline $\begin{array}{c}\text { Lower } \\
\text { Extremity }\end{array}$ & 4 & 11 & 19 & 13 & 6 \\
\hline Chest & 31 & 26 & 32 & 21 & 30 \\
\hline Abdomen & 20 & 16 & Nil & 17 & 20 \\
\hline Back & 8 & 15 & 5 & 11 & 16 \\
\hline Perineum & 8 & 3 & 5 & 5 & 6 \\
\hline Total & $\mathbf{1 0 0}$ & \multicolumn{1}{|c|}{$\mathbf{1 0 0}$} & $\mathbf{1 0 0}$ & $\mathbf{1 0 0}$ & $\mathbf{1 0 0}$ \\
\hline \multicolumn{7}{|c|}{ Table 2: Comparison of Site of } \\
\hline
\end{tabular}

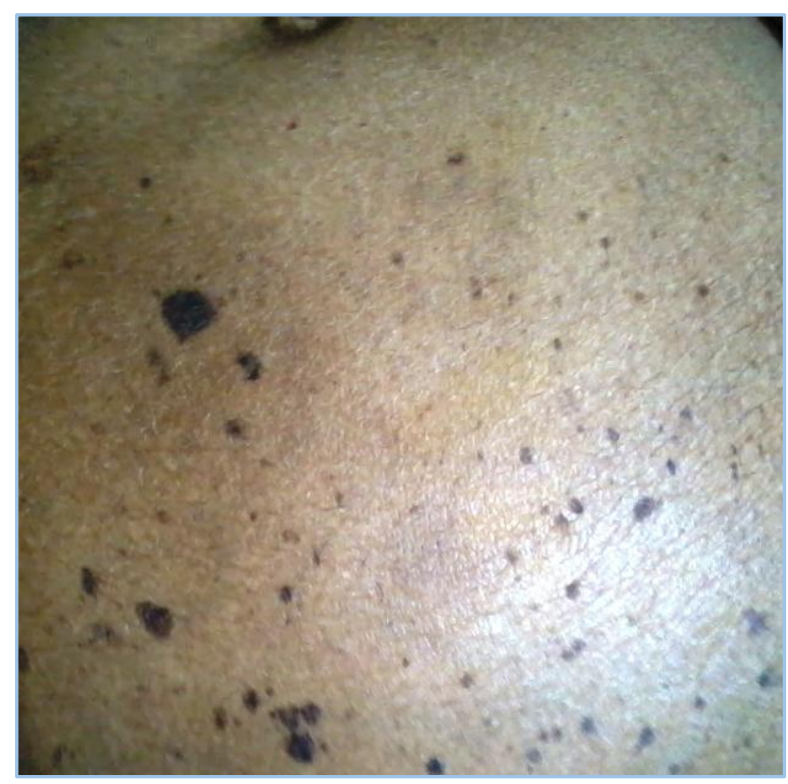

Fig. 1: Metastatic Nodules over Abdomen in Hepatocellular Carcinoma

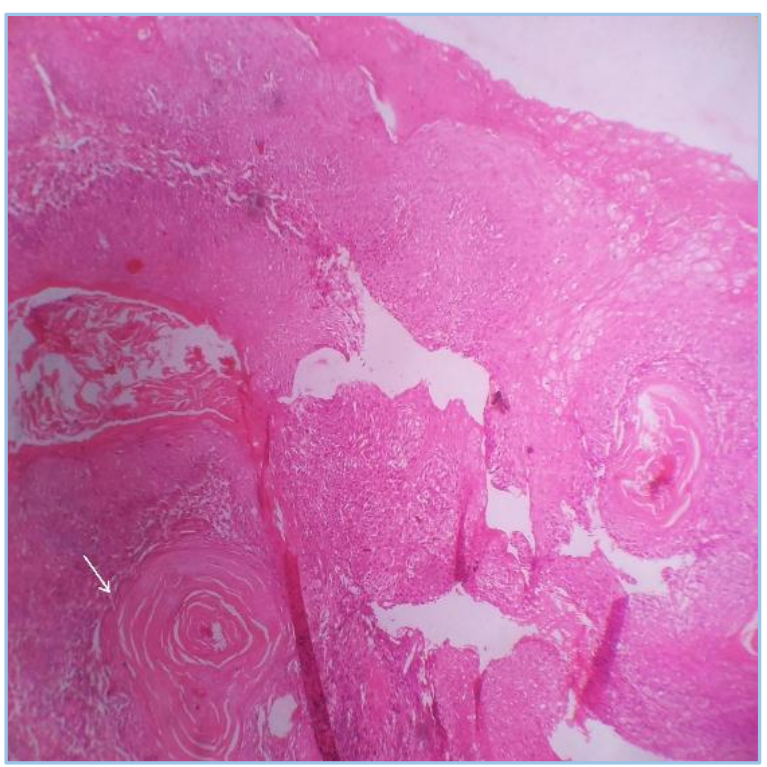

Fig. 2: Biopsy Ulcer Tongue-Squamous Cell Carcinoma with Epithelial Pearls (Arrow) seen. H\&E Stain, 10x

\section{DISCUSSION}

In malignant tumour, metastasis is known but skin is an infrequent site for metastasis and listed in one study as only the eighteenth most common site. ${ }^{1}$ Cutaneous metastasis can 
arise at any age, but most cutaneous metastasis occurred during or after the fifth decade.2,3 Cutaneous metastasis can arise at any age. In the present study cutaneous metastases were $50 \%$ in fifth decade and above, which correlates with study of Rajagopal et al.

Cutaneous metastasis of primary malignant lesions occurs in $3-4 \%$ of patients in different studies. ${ }^{1}$ Cutaneous metastatic lesions are usually multiple and may range from 1 to $100.3,4$

In the present study cutaneous metastases is $6 \%$, in which contiguous $5 \%$ and non-contiguous $1 \%$ and increase in incidence is due to direct infiltration of skin or through lymphatics or through blood vessels, which correlates with study of Rajagopal et al. According to Brownstein et al, the most common internal malignancy which gives rise to cutaneous metastasis was carcinoma lung and colon in males, carcinoma colon and ovary in females. Overall melanomas are commonest followed by carcinoma breast, carcinoma oral cavity, lungs, colon and ovary. 5

In the present study the carcinoma oropharynx was $15 \%$, followed by carcinoma oesophagus, cervix and breast $10 \%$ each, carcinoma oral cavity 7\%, carcinoma larynx, rectum, stomach, ovary and acute lymphatic leukaemia were $6 \%$ each and lung $3 \%$. The commonest malignancy in males was carcinoma oropharynx (12\%) followed by oesophagus (7\%), oral cavity $(6 \%)$, larynx $(6 \%)$ and in females, carcinoma of breast (10\%), cervix (10\%) and ovary (6\%). Brownstein et al stated that carcinoma oesophagus was an uncommon cause for cutaneous metastasis responsible only in 15 (2\%) of 724 cases and $9(1.5 \%)$ of 588 cases of cutaneous metastasis. ${ }^{5}$ According to Brownstein et al and Thakaram S, anterior chest wall is the commonest site of cutaneous metastatic lesion. 5,6

In the present study, carcinoma breast causing cutaneous metastases seen in 2 cases and one case each in carcinoma oropharynx, nasopharynx, liver and penis. According to Theirs et al, survival period in patients with cutaneous metastasis is said to be around 3 months. ${ }^{7}$ Abrams et al stated that skin is the infrequent site for metastasis and skin lesions are often easily accessible for biopsy and histopathological examination. ${ }^{8}$

In the present study metastatic skin lesions of carcinoma oropharynx involves face, neck and chest. Hepatocellular carcinoma (Figure 1) and nasopharyngeal carcinoma involves face, neck, chest, back, abdomen, arm and thigh. Carcinoma penis involves perineum and carcinoma breast involves the chest.

According to some authors most common malignant tumour that metastasises to skin was carcinoma lung and breast. The lesions on face, scalp, chest and shoulder may be the only presenting feature of unsuspected primary tumour and histopathology reveals the identity of the primary tumour. 9,10

In the present study, squamous cell carcinoma was the commonest type (Figure 2). The commonest site for cutaneous metastasis was chest (30\%) followed by abdomen (20\%), back $(16 \%)$, neck $(9 \%)$, upper extremity $(8 \%)$, lower extremity $(6 \%)$, perineum $(6 \%)$, face $(5 \%)$ (Table 2) and it correlates with study of Brownstein et al and Thakaram S.

Delaney WE et al, report that longer survival for periods ranging from 1 to 4 to even 10 years. ${ }^{11}$

In the present study patients survived for 6 months to 2 years after treatment, but 5 years followup is required to know the outcome.
According to Welch JL et al, 3 non-specific skin changes were found with increased predisposition in patients with malignant diseases as compared to control and those were acquired ichthyosis, generalized pruritus and herpes zoster.

All the cases of acquired ichthyosis had lymphomas. Both acquired ichthyosis and generalized pruritus were more common in Hodgkin's lymphoma than in non-Hodgkin's lymphoma. 12

In the present study nonspecific skin changes seen in 9 $(9 \%)$ cases, in which commonest was acquired ichthyosis, 3 $(3 \%)$ seen in carcinoma oesophagus, $2(2 \%)$ in carcinoma stomach and $1(1 \%)$ in non-Hodgkin's lymphoma. Generalized pruritus, petechial haemorrhage and acanthosis nigricans one each in hepatocellular carcinoma, acute lymphatic leukaemia and carcinoma breast respectively. Drug reaction noticed in one case of carcinoma rectum to Zoledronic acid infusion and patient had developed generalized maculopapular rashes.

\section{CONCLUSION}

Cutaneous metastases are relatively uncommon and occur late in malignancy. Non-specific skin lesions are common compared to specific skin lesions. Contiguous metastases are more common in breast malignancy and often herald the recurrence after surgery. The incidence of cutaneous metastasis is common in patients who belong to low socioeconomic group and who indulge in smoking, alcohol consumption and tobacco chewing. Cutaneous metastasis indicates there may be wide spread metastasis to distant site. Early recognition and treatment of cutaneous metastasis will help in prolonging the life of patient.

\section{REFERENCES}

1. Rajagopal R, Arora PN, Ramasastry CV, et al. Skin changes in internal malignancy. Indian J Dermatol venereol leprol 2004;70(4):221-5.

2. Rosen T. Cutaneous metastases. Med Clin North Am 1980;64(5):885-900.

3. Ayyamperumal A, Tharini GK, Ravindran V, et al. Cutaneous manifestations of internal malignancy. Indian J Dermatol 2012;57(4):260-4.

4. Gates O. Cutaneous metastases of malignant disease. Am J Cancer 1937;30(4):718-30.

5. Brownstein $\mathrm{MH}$, Helwig EB. Patterns of cutaneous metastasis. Arch Dermatol 1972;105(6):862-8.

6. Thakaram S. Metastases to the skin. Int J Dermatol 1988;27(4):240-2.

7. Thiers BH, Sahn RE, Callen JP. Cutaneous manifestations of internal malignancy. CA Cancer J Clin 2009;59:73-98.

8. Abrams HL, Spiro R, Goldstein N. Metastases in carcinoma: analysis of 1000 autopsied cases. Cancer 1950;3(1):74-85

9. Rao GM, Pavani M, Giridhar T, et al. Cutaneous metastasis of internal malignancy. J DR NTR Univ Health Sci 2013;2(2):122-4.

10. Ruben S, Owen D, Lee P, et al. Hepatocellular carcinoma with cutaneous metastasis. Can J Gastroenterol 2009;23(1):23-5.

11. Delaney WE, Fay KE. Long survival after solitary distant metastasis from carcinoma of the colon. Dis Colon Rect 1966;9:420-2.

12. Welch JL, Epstein E. Acquired ichthyosis in Hodgkin's disease. JAMA 1952;148(14):1221-3. 